\title{
Combined Iodine, Iron and Zinc Biofortification of Tomato Fruit
}

\section{Özge ŞAHIN ${ }^{1 *}$}

\begin{abstract}
Deficiencies of zinc ( $\mathrm{Zn})$, iron (Fe) and iodine (I) are major malnutritional health problem in the devoloping countries. Biofortification of vegetables with I, Fe and $\mathrm{Zn}$ can become an alternative strategy of introducing these elements for human dietary intake. The purpose of this study was to determine the effect of combined $\mathrm{I}\left(\mathrm{KIO}_{3}\right), \mathrm{Fe}\left(\mathrm{FeSO}_{4} .7 \mathrm{H}_{2} \mathrm{O}\right)$ and $\mathrm{Zn}\left(\mathrm{ZnSO}_{4} .7 \mathrm{H}_{2} \mathrm{O}\right)$ supply on $\mathrm{I}, \mathrm{Fe}$ and $\mathrm{Zn}$ concentrations of tomato plants, which is stem and leaf, and their fruits (Lycopersicon esculentum $\mathrm{L}$. cv. Swanson). Tomato cultivar was grown in glasshouse conditions with four replications in $10 \mathrm{~kg}$ soil and 5\% peat mixture. The treatments as contain: contol, each element applied at 10, 20 and $40 \mathrm{mg} \mathrm{I-Fe}-$ $\mathrm{Zn} \mathrm{kg}^{-1}$, respectively. Concentrations of I, Fe and $\mathrm{Zn}$ and essential elements ( $\mathrm{P}, \mathrm{K}, \mathrm{Ca}, \mathrm{Mg}, \mathrm{S}, \mathrm{Cu}, \mathrm{Mn}$, $\mathrm{Mo}, \mathrm{Cl}, \mathrm{Si}$ and $\mathrm{Ni}$ ) as well as non-essential elements (Al, Co, Ti, Br, Rb, Sr, Ba, Cr, Sn, Sb, Te, Ge, Cs, $\mathrm{Ce}, \mathrm{Ga}, \mathrm{Ta}, \mathrm{Hf}$ ) were determined by Polarized Energy Dispersive X-ray Fluorensence (PEDXRF). Effect of combined I-Fe-Zn treatments on fresh and dry weights of plant and fruit were found statistically important. Iron and $\mathrm{Zn}$ concentrations of fruits and plants were increased by combined I-Fe-Zn treatment except for Fe concentration in plant. Application of I-Fe-Zn were not significant effect on essential element concentrations in both plants and fruits, out of $\mathrm{Ca}, \mathrm{Na}$ and $\mathrm{Si}$ concentrations in fruit. No influence of I-Fe-Zn treatment on the measured non-essential elements concentrations with the exception of plant $\mathrm{Br}$ concentration and fruit $\mathrm{Sr}$ concentration. This study revealed that combined I-Fe-Zn treatment can be used effectively for I, Fe and Zn biofortication of tomato fruits for the dietary intake for human.
\end{abstract}

Key words: Biofortification, iodine, iron, zinc, tomato (Lycopersicon esculentum)

${ }^{1}$ Özge ŞAHIN (Orcid ID: 0000-0003-3593-4594), Ankara Üniversitesi, Ziraat Fakültesi, Toprak Bilimi ve Bitki Besleme Bölümü, Ankara, Türkiye

*Sorumlu Yazar/Corresponding Author: Özge ŞAHIN, e-mail: osahin@ankara.edu.tr

Geliş tarihi / Received: 21-02-2020

Kabul tarihi / Accepted: 06-04-2020 


\section{INTRODUCTION}

Micronutrient malnutrition is an inadequate daily diet of iron (Fe), zinc ( $\mathrm{Zn})$ and iodine (I) (Stein, 2010; Clemens, 2014) and deficienciey of these nutrition is a reason of serious health problem on world population especially in devolopping countries (Welch et al., 2013; Cakmak and Kutman, 2018; Zou et al., 2019). There are some methods to combat nutrient deficiency such as biofortification, specific plants, transgenic plants or conventional breeding and etc. (Dimkpa and Bindraban, 2016; Kumar et al., 2019) but biofortification is the more impactful, sustainable, low-cost and easier method to enrich the micronutrient content of crops than the other methods for developing countries (Bouis et al., 2011; DiazGomez et al., 2017; Sazawal et al., 2018).

Iodine, $\mathrm{Fe}$ and $\mathrm{Zn}$ are essential micronutrient for human health and unfortunately, deficiencies are common in both developing and developed countries. Iodine necessity of people is about $150 \mu \mathrm{g} \mathrm{day}^{-1}$ which is especially need for activity of thyroid hormones, besides infant mortalities, mental retardation (Lin et al., 2004; Smolen and Sady, 2012). Anemia is the one of the common health problem by the reason of Fe deficiency, especially about $40-45 \%$ of prescholl-age children are anemic, which more than half of the Fe in the human body is bound to hemoglabine (Grillet et al., 2014). The recommended human dietary of Fe varies between 8-18 $\mathrm{mg} \mathrm{day}^{-1}$ depending on the age, body weight, gender and pregnancy (Anonymous, 2009). Zinc is structural role on thousands of proteins for microorganisms, plants, animals and humans. People daily $\mathrm{Zn}$ requirement is $1.5-2.5 \mathrm{mg} \mathrm{day}^{-1}$ and due to the deficiency of $\mathrm{Zn}$ may occur retarded growth, skeletal abnormalities, hypogonadism, diarrhea, immune dysfunction, delayed wound healing etc. (Salgueiro et al., 2000; Anonymous, 2009; Anonymous, 2017).

Deficiency of reasons of $\mathrm{I}, \mathrm{Zn}$ and $\mathrm{Fe}$ in soil and plant are soil texture, $\mathrm{pH}$, tillage, water management, nutrient interactions, fertilization, type of nutriets and plant cultivars (Hetzel and Pandav, 1994; Lin et al., 2004, Smolen and Sady, 2012; Prasad et al., 2014; Patel et al., 2018; Gonzali et al., 2017; Lyons, 2018). In addition, main important reason of deficieny of I, Fe and Zn concentration is phytic acid. Phytic acid is a compound, which found especially in cereals and therefore has an important influence in daily human food consumption. Unfortunately, bioavailability of some element such as $\mathrm{Zn}$, Fe are relationship with phytic acid. Because, phytic acid obstructed the availability of these element in cereals which there are many studies about it (Cakmak et al., 2010; White and Broadley, 2011; Sperotto et al., 2012; Shahzad et al., 2014; Guo et al., 2016; Maqbool and Beshir, 2018; Cakmak and Kutman, 2018). While vegetables have low phytic acid and high ascorbate content as well as phenolics and carotenoids that it is increased availability of these elements (Gillooly et al., 1983; Siegenberg et al., 1991; Garcia-Alonso et al., 2004; La Frano et al., 2014; Krzepilko et al., 2015; Woch and HawrylakNowak, 2019; Giordano et al., 2019). In these way biofortification of vegetable is an alternative to suppress on the phytic acid metabolism (Majumber et al., 2019). Besides, vegetables such as spinach, lettuce, tomato etc. are short-term growing than the cereals which means that people can uptake nutrient is more quickly and easily. At the same time inceases of concentrations of I, Fe and Zn not only effect on the concentrations of deficit nutrients but also increase the antioxidant compound of plants and so increases of these nutrients will have a positive effect on human health (Blasco et al., 2008; Przybysz et al., 2016; Incrocci et al., 2019).

Among the vegetables, tomato is the most consumed and traded vegetables in the world and it has important nutrients and antioxidants which plays an important role in human diet, especially for vegetarian diet. Additionally, tomato is not only used as a fresh but also it uses as a souce, paste, dried, peeled etc. There is some study about $\mathrm{Zn}$ and Fe biofortification on most important cereal like maize, rice or wheat etc. (Cakmak et al., 2010; Sperotto et al., 2012; White and Broadley, 2011; Guo et al., 
2016; Maqbool and Beshir, 2018; Cakmak and Kutman, 2018). Unfortunately, there is not any study on the combined I, Fe and Zn biofortification of edible plants (Kiferli et al., 2013; La Frano et al., 2014; Krzepilko et al., 2015; 2016; Giordano et al., 2019).

The aim of this study is to find out I, Fe and Zn biofortification with the supply of those elements and also determine the variations of essential ( $\mathrm{K}, \mathrm{P}, \mathrm{Ca}, \mathrm{Mg}, \mathrm{S}, \mathrm{Cu}, \mathrm{Mn}, \mathrm{Mo}, \mathrm{Cl}, \mathrm{Si}$ and $\mathrm{Ni}$ ) and some non-essential (Co, Ti, Br, Rb, Sr, Ba, Cr, Sn, Sb, Te, Ge, Cs, La, Ce, Ga, Ta, Hf,) elements concentrations of tomato plants and fruits. This is the first study about combine I, Fe and $\mathrm{Zn}$ biofortification on vegetables and I expect this study to lead the new studies with other vegetables.

\section{MATERIALS AND METHODS}

\section{Plant Growth Conditions and Treatments}

Tomato plants (Lycopersicon esculentum Mill. cv. Swanson) were grown from May 23 to August 16, 2018 in a glasshouse condition at the Department of Soil Science and Plant Nutrition, Ankara University. The experiment was carried out in plastic pots $(30 \mathrm{~cm} \times 24 \mathrm{~cm} \times 27 \mathrm{~cm})$ holding $10,000 \mathrm{~g}$ airdried soil and $5 \%$ peat of total soil weight. The soil was taken from the $0-20 \mathrm{~cm}$ of experimental fields of the Agricultural Faculty, Ankara University and properties of the soil were determined by the Page (1982) (Table 1). For each element from I $\left(\mathrm{KIO}_{3}\right), \mathrm{Fe}\left(\mathrm{FeSO}_{4} .7 \mathrm{H}_{2} \mathrm{O}\right)$ and $\mathrm{Zn}\left(\mathrm{ZnSO}_{4} .7 \mathrm{H}_{2} \mathrm{O}\right)$ were applied at the rates of $0,10,20$ and $40 \mathrm{mg} \mathrm{kg}^{-1}$ of soil after the seedling transplantation, respectively. For the basal fertilization, $400 \mathrm{mg} \mathrm{N} \mathrm{kg}^{-1}$ soil from $\mathrm{KNO}_{3}$ and $100 \mathrm{mg} \mathrm{N} \mathrm{kg}^{-1}$ from $\mathrm{CaNO}_{3}, 100 \mathrm{mg} \mathrm{\textrm {Pg } ^ { - 1 }}$ from $\left(\mathrm{NH}_{4}\right) \mathrm{H}_{2} \mathrm{PO}_{4}$ ' which total amount of $\mathrm{N}, \mathrm{P}, \mathrm{K}$ and Ca was 545, 100, 1110, $170 \mathrm{mg} \mathrm{kg}^{-1}$ respectively, were applied during the plant growth period. The experiment was designed according to a randomized block design with four replications-one plant per one replicate in each treatment. Plants were irrigated with tap water until reached the $70 \%$ of field capacity. Plants were cultivated until the bud of the inflorescences in the four cluster was formed. Ripening fruits and leaves were collected for each cluster, weighed and dried during the experiment. Plants were harvested and separated into leaf and stem (plant) and unripened fruits. After determining of fresh weight, the plants and fruits were washed once with tap water and twice in deionized water. Four cluster of plants and fruits were combined with each other, seperately. Unripened fruits were omitted after weighing while concentrations of elements were determined in only ripening fruits. Plant and fruit samples, which are expressed as homogenized leaf and stem and fruit samples, were dried in a drying oven at $65^{\circ} \mathrm{C}$ and then dry weight recorded. All samples were grounded. Before the determination of elemental concentrations by PEDXRF elemental analysis, samples were pelleted with press machine.

\section{Determination of Mineral Element Concentraions of Soil, Plant and Fruit}

Homogenied plants and fruit samples were sieved $(200 \mu \mathrm{m})$ to determine of the essential and nonessential element concentraitions by PEDXRF (Spectro XLAB2000) as reported by Gunes et al., (2009) at the Earth Sciences Application and Research Centre (YEBIM) of Ankara University.

\section{Statistical Analysis}

Analysis of variance was performed on the data with one-way ANOVA using MINITAB 17 and significant differences among treatment means were calculated by LSD test (LSD; $P<0.05$ ) and compared by descriptive statistics $[ \pm$ standart error $(\mathrm{SE})]$. 
Table 1. Some physical and chemical properties of soil

\begin{tabular}{|c|c|c|c|}
\hline Properties & \multicolumn{2}{|l|}{ Method } & Amount/ Quantification \\
\hline Texture & \multicolumn{2}{|l|}{-} & Loamy \\
\hline $\mathrm{CaCO}_{3}$ & Scheibler & & $59.60 \mathrm{~g} \mathrm{~kg}^{-1}$ \\
\hline $\mathrm{pH}$ & $1 / 2.5$ water & & 7.80 \\
\hline EC & $1 / 2.5$ water & & $0.35 \mathrm{dS} \mathrm{m}^{-1}$ \\
\hline Organic Matter & Walkley Black & & $18.20 \mathrm{~g} \mathrm{~kg}^{-1}$ \\
\hline $\mathrm{N}$ & Kjeldahl & & $3.52 \mathrm{~g} \mathrm{~kg}^{-1}$ \\
\hline \multicolumn{4}{|c|}{ Concentration of elements $\left(\mathrm{NH}_{4} \mathrm{OAc}\right.$-extractable, $\left.\mathrm{g} \mathrm{kg}^{-1}\right)$} \\
\hline K & 0.79 & $\mathrm{Mg}$ & 1.86 \\
\hline $\mathrm{Ca}$ & 5.10 & $\mathrm{Na}$ & 0.25 \\
\hline \multicolumn{4}{|c|}{ Concentration of elements (DTPA-extractable, $\mathrm{mg} \mathrm{kg}^{-1}$ ) } \\
\hline $\mathrm{Fe}$ & 8.73 & $\mathrm{Cu}$ & 2.06 \\
\hline $\mathrm{Zn}$ & 4.02 & $\mathrm{Mn}$ & 22.6 \\
\hline \multicolumn{4}{|c|}{ Total concentrations of elements (XRF, $\left.\mathrm{g} \mathrm{kg}^{-1}\right)$} \\
\hline $\mathrm{P}$ & 0.97 & $\mathrm{Na}$ & 0.37 \\
\hline K & 13.9 & $\mathrm{Cl}$ & 0.05 \\
\hline $\mathrm{Ca}$ & 47.7 & $\mathrm{Si}$ & 155 \\
\hline $\mathrm{Mg}$ & 9.23 & $\mathrm{Al}$ & 42.68 \\
\hline$S$ & 1.01 & - & - \\
\hline \multicolumn{4}{|c|}{ Total concentrations of elements $\left(\mathrm{mg} \mathrm{kg}^{-1}\right)$} \\
\hline I & 2.30 & $\mathrm{Ba}$ & 452 \\
\hline $\mathrm{Fe}$ & 32570 & $\mathrm{Sb}$ & 1.60 \\
\hline $\mathrm{Zn}$ & 123 & $\mathrm{Sn}$ & 7.20 \\
\hline $\mathrm{Cu}$ & 41.20 & $\mathrm{Rb}$ & 58.04 \\
\hline $\mathrm{Mn}$ & 703 & $\mathrm{Cr}$ & 72.12 \\
\hline Mo & 2.70 & $\mathrm{Ga}$ & 13.60 \\
\hline $\mathrm{Se}$ & 0.30 & $\mathrm{Ge}$ & 1.00 \\
\hline $\mathrm{Cd}$ & 0.80 & Cs & 3.80 \\
\hline Co & 37.50 & $\mathrm{Ta}$ & 4.20 \\
\hline $\mathrm{Br}$ & 3.90 & $\mathrm{Te}$ & 1.20 \\
\hline $\mathrm{Ti}$ & 3288 & $\mathrm{Ce}$ & 60.30 \\
\hline $\mathrm{Ni}$ & 54.70 & $\mathrm{Hf}$ & 4.00 \\
\hline $\mathrm{Sr}$ & 256 & - & - \\
\hline
\end{tabular}

\section{RESULTS AND DISCUSSION}

\section{Dry and Fresh Weight of Plant and Fruit}

Plant and fruit weight of the tomatoes was presented in Table 2. Biofortification with I-Fe-Zn had positive effect on plant and fruit weight. Effect of combined I-Fe-Zn treatments on dry and fresh weight of plant and fruit were statistically important. The highest fresh and dry weight of plant were determined by $10 \mathrm{mg} \mathrm{I-Fe-Zn} \mathrm{kg}{ }^{-1}$ of soil, respectively $472,79.50$. There was a relationship between the levels of I$\mathrm{Fe}-\mathrm{Zn}$ and fruit weight. Fruit fresh weight increased by the combined I-Fe-Zn treatments and the highest fruit weight were determined by the highest level of combined I-Fe-Zn treatment (40 mg I-Fe-Zn kg-1 of soil). Especially, fruit weights were increased by the combined I-Fe-Zn treatments, respectively $16 \%$, $47 \%, 74 \%$ when compared the control treatment. This result is accordance with the study of Weng et al. (2013) who explained that I had positive effect on biomass of 10 different vegetables cultivars. Weng et al. (2008) in their study showed that I treatmant is effective on growth rate of spinach. Blasco et al., (2008), concentration of I and antioxidant compounds of lettuce were increased due to the treatment of I. Gioia et al. (2019) suggested that growth rate with Fe and Zn concentrations of microgreen plants were increased by the Fe and $\mathrm{Zn}$ treatments. 
Table 2. Effect of combined iodine, iron and zinc treatment on plant fresh and dry weight, and fruit weight

\begin{tabular}{llll}
\hline \multirow{2}{*}{ Treatments } & \multicolumn{1}{c}{ Plant } & Fruit & $\begin{array}{l}\text { Fresh weight } \\
\text { g fruit }^{-1}\end{array}$ \\
\cline { 2 - 4 } g plant $^{-1}$ & $\begin{array}{l}\text { Fresh weight } \\
\text { g plant }^{-1}\end{array}$ & $53.22 \pm 4.22 \mathrm{c}$ & $522 \pm 22.62 \mathrm{~d}$ \\
\hline Control & $254 \pm 11.41 \mathrm{c}$ & $79.50 \pm 4.52 \mathrm{a}$ & $607 \pm 19.00 \mathrm{c}$ \\
$\mathbf{1 0}$ I-Fe-Zn & $472 \pm 12.48 \mathrm{a}$ & $63.92 \pm 1.75 \mathrm{~b}$ & $766 \pm 16.50 \mathrm{~b}$ \\
$\mathbf{2 0}$ I-Fe-Zn & $360 \pm 8.34 \mathrm{~b}$ & $64.28 \pm 0.48 \mathrm{~b}$ & $906 \pm 5.87 \mathrm{a}$ \\
$\mathbf{4 0}$ I-Fe-Zn & $372 \pm 9.55 \mathrm{~b}$ & 11.68 & 98.26 \\
\hline$F$ & 71.27 & $9.74 * *$ & $26.63 * *$ \\
\hline
\end{tabular}

** $P<0.01$

\section{Concentrations of the Elements}

Plant I concentrations were increased by the combined treatment of I, Fe and $\mathrm{Zn}$. The highest concentrations of I and $\mathrm{Zn}$ in the plants were determined by the $40 \mathrm{mg} \mathrm{kg}^{-1}$ of soil. However, concentration of $\mathrm{Fe}$ in plant were not change statististically important. The highest concentrations of $\mathrm{I}$, $\mathrm{Fe}$ and $\mathrm{Zn}$ in the fruits were determined by highest combine I-Fe-Zn treatment $\left(40 \mathrm{mg} \mathrm{kg}^{-1}\right)$ as $19.9,39.7$ and $39.6 \mathrm{mg} \mathrm{kg}^{-1}$ in fruit, respectively (Table 3). Iodine concentrations of plants and fruits were increased due to the increases treatment levels that the highest I concentration were determined by the highest combine treatment, but there was no statistically important difference between the other treatment. Zinc and $\mathrm{Fe}$ concentrations of fruits were increased by the the treatments. Some studies demonstrated that some vegetables and fruits such as spinach (Zhu et al., 2003; Weng et al., 2003; Dai et al., 2006; Humphrey et al., 2019), lettuce (Blasco et al., 2008; Voogt et al., 2010), radish and Chinese cabbage (Weng et al., 2003), strawberry (Li et al., 2017a), pepper (Li et al., 2017b) can store I by levels of I treatment. According LandiNI et al., (2011) fresh weight and I concentration of tomato (Solanum lycopersicum L.) were increased by I treatment $(5,10$ and $20 \mathrm{mM})$ and as a result, $5 \mathrm{mM}$ I treatment was enough to uptake a daily human I requirement. Hong et al. (2008) reported that higher than $50 \mathrm{mg} \mathrm{I} \mathrm{kg}^{-}$ ${ }^{1}$ of soil treatment was shown chlorosis effect on tomato. In the other study by Weng et al. (2013) reported that biofortification of I can be changed due to the different genotypes within the same type of vegetables and levels of treatments. All of these studies results like our results. Iron and $\mathrm{Zn}$ concentration of tomato fruits were increased by the I, Fe and $\mathrm{Zn}$ treatments. Especially, effect of the highest combined $\mathrm{I}, \mathrm{Fe}$ and $\mathrm{Zn}$ treatment on $\mathrm{Fe}$ and $\mathrm{Zn}$ concentraions of fruits were remarkable than the other treatment. Researches conducted by Cakmak (2008), Prasad et al. (2014), White and Broadley (2009, 2011), Shahzad et al. (2014), Zaman et al. (2018), Patel et al. (2018), Giardono et al. (2019) shows that combined or separately application of $\mathrm{Zn}$ and $\mathrm{Fe}$ was reason of the increases of $\mathrm{Fe}$ and $\mathrm{Zn}$ concentrations as in this research.

Table 3. Effect of combined iodine, iron and zinc treatment on plant and fruit I, Fe and $\mathrm{Zn}$ concentrations

\begin{tabular}{|c|c|c|c|}
\hline \multirow{2}{*}{ Treatments } & \multicolumn{3}{|c|}{ Plant (mg kg ${ }^{-1}$ DW) } \\
\hline & I & $\mathbf{F e}$ & Zn \\
\hline Control & $2.50 \pm 0.24 \mathrm{c}$ & $210 \pm 26.20$ & $16.90 \pm 1.30 \mathrm{~d}$ \\
\hline 10 I-Fe-Zn & $68.50 \pm 13.0 \mathrm{bc}$ & $188 \pm 11.10$ & $30.80 \pm 0.85 \mathrm{c}$ \\
\hline 20 I-Fe-Zn & $162 \pm 27.02 \mathrm{~b}$ & $221 \pm 20.10$ & $40.90 \pm 1.94 \mathrm{~b}$ \\
\hline 40 I-Fe-Zn & $308 \pm 60.62 \mathrm{a}$ & $197 \pm 15.50$ & $55.30 \pm 4.48 \mathrm{a}$ \\
\hline$F$ & 15.4 & 0.57 & 26.2 \\
\hline \multirow[t]{2}{*}{ LSD } & $104 * *$ & ns & $7.89 * *$ \\
\hline & \multicolumn{3}{|c|}{ Fruit (mg kg-1 DW) } \\
\hline Control & $2.73 \pm 0.30 \mathrm{~b}$ & $28.75 \pm 1.11 \mathrm{c}$ & $21.05 \pm 1.34 \mathrm{c}$ \\
\hline 10 I-Fe-Zn & $2.74 \pm 0.29 \mathrm{~b}$ & $30.83 \pm 1.57 \mathrm{bc}$ & $28.52 \pm 1.28 \mathrm{~b}$ \\
\hline 20 I-Fe-Zn & $5.24 \pm 1.77 \mathrm{~b}$ & $32.39 \pm 0.91 \mathrm{~b}$ & $29.70 \pm 0.94 \mathrm{~b}$ \\
\hline 40 I-Fe-Zn & $19.85 \pm 2.71 \mathrm{a}$ & $39.64 \pm 1.03 \mathrm{a}$ & $39.58 \pm 1.54 \mathrm{a}$ \\
\hline$F$ & 25.37 & 16.10 & 35.54 \\
\hline LSD & $5.03 * *$ & $3.64 * *$ & $3.99 * *$ \\
\hline
\end{tabular}

ns, non-significant; $* * P<0.01$. 
Treatments of combined I-Fe-Zn had no statistically important effect on the concentrations of $\mathrm{P}$, $\mathrm{K}, \mathrm{Mg}, \mathrm{Na}, \mathrm{S}, \mathrm{Ca}, \mathrm{Si}$ and $\mathrm{Al}$ of plants. On the other hand, effect of treatments (40 mg I-Fe-Zn kg-1 of soil) on $\mathrm{Ca}, \mathrm{Na}$ and $\mathrm{Si}$ concentrations of fruit were statistically important while $\mathrm{P}, \mathrm{K}, \mathrm{S}$ and $\mathrm{Mg}$ of fruit were not statistically important (Table 4). Essential and non-essential elements concentrations of plant and fruit were not signifcantly changed by combined I, Fe and Zn treatments. In the study conducted by Smolen and Sandy (2012) effect of I treatment on P, K, Mg, S, B, Cu, Mn, Mo and Cd concentrations in spinach were not signinificant. On the contrary, concentrations of $\mathrm{N}, \mathrm{Ca}, \mathrm{Na}, \mathrm{Fe}$ and $\mathrm{Zn}$ of plant were significantly increased by I treatment. Islam et al. (2018) were examined the effect of Fe and I treatment

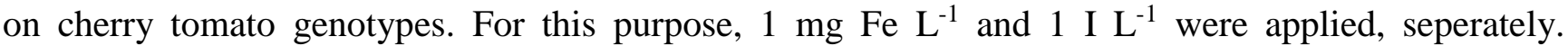
Treatments of these elements were not significant effect on $\mathrm{Fe}, \mathrm{Mn}, \mathrm{Cu}$ and $\mathrm{Zn}$ concentrations. In an another study by Krezpilko et al. (2016), $0.5 \mu \mathrm{M} \mathrm{KI} \mathrm{L}^{-1}$ treatment was sufficient to enrich seedlings with I and $\mathrm{K}$; however, effect of this treatment was not significant effect on $\mathrm{Ca}, \mathrm{Zn}, \mathrm{Fe}$ and $\mathrm{Cu}$ concentration. Krzepiłko et al. (2015) who reported I positive affected the uptake of $\mathrm{Mg}, \mathrm{Na}, \mathrm{Ca}$ and $\mathrm{Fe}$ but negative affected Cr uptake in the spinach plant. Smolen and Sady (2011), I treatment was increased the concentrations of $\mathrm{Na}, \mathrm{Fe}, \mathrm{Zn}$ and $\mathrm{Al}$ and reduced concentrations of $\mathrm{P}, \mathrm{S}, \mathrm{Cu}$ and $\mathrm{Ba}$ concentrations. All of these results show that levels of mineral element concentrations can be change due to the level of I, and $\mathrm{Zn}$ treatment and plant genotypes. All of these results of different researcher were showed that concentrations of some essential and non-essential element can change by the levels of treatments and plant cultivars.

Table 4. Effect of combined iodine, iron and zinc treatment on plant and fruit $\mathrm{P}, \mathrm{K}, \mathrm{S}, \mathrm{Ca}, \mathrm{Mg}, \mathrm{Na}, \mathrm{Si}$ and $\mathrm{Al}$ concentrations

\begin{tabular}{|c|c|c|c|c|c|c|c|c|}
\hline \multirow{2}{*}{ Treatments } & \multicolumn{8}{|c|}{ Plant $\left(\mathrm{g} \mathrm{kg}^{-1} \mathrm{DW}\right)$} \\
\hline & $\mathbf{P}$ & $\mathbf{K}$ & $\mathbf{S}$ & $\mathbf{C a}$ & Mg & $\mathbf{N a}$ & $\mathbf{S i}$ & Al \\
\hline Control & $1.85 \pm 0.16$ & $27.80 \pm 1.43$ & $7.20 \pm 0.97$ & $34.7 \pm 5.62$ & $5.90 \pm 1.27$ & $3.60 \pm 0.88$ & $2.20 \pm 0.17$ & $0.58 \pm 0.06$ \\
\hline 10 I-Fe-Zn & $2.16 \pm 0.11$ & $28.83 \pm 1.74$ & $8.35 \pm 0.60$ & $36.9 \pm 3.09$ & $6.52 \pm 0.63$ & $3.98 \pm 0.67$ & $2.08 \pm 0.13$ & $0.48 \pm 0.02$ \\
\hline 20 I-Fe-Zn & $2.05 \pm 0.27$ & $27.98 \pm 1.51$ & $8.48 \pm 0.54$ & $39.2 \pm 1.60$ & $6.45 \pm 0.34$ & $3.40 \pm 0.65$ & $2.09 \pm 0.11$ & $0.53 \pm 0.02$ \\
\hline 40 I-Fe-Zn & $2.02 \pm 0.05$ & $24.59 \pm 0.32$ & $8.77 \pm 0.51$ & $41.4 \pm 1.78$ & $6.80 \pm 0.38$ & $3.60 \pm 0.31$ & $2.17 \pm 0.11$ & $0.48 \pm 0.02$ \\
\hline$F$ & 0.60 & 1.86 & 1.04 & 0.71 & 0.25 & 0.39 & 0.20 & 1.84 \\
\hline \multirow[t]{2}{*}{ LSD } & ns & ns & ns & ns & ns & ns & ns & ns \\
\hline & \multicolumn{8}{|c|}{ Fruit $\left(\mathrm{g} \mathrm{kg}^{-1} \mathrm{DW}\right)$} \\
\hline 10 I-Fe-Zn & $3.52 \pm 0.15$ & $42.77 \pm 2.13$ & $1.79 \pm 0.12$ & $0.68 \pm 0.02 b$ & $1.18 \pm 0.17$ & $0.24 \pm 0.00 \mathrm{~b}$ & $0.68 \pm 0.01 \mathrm{~b}$ & $0.32 \pm 0.00$ \\
\hline 20 I-Fe-Zn & $3.33 \pm 0.12$ & $43.39 \pm 2.47$ & $1.75 \pm 0.07$ & $0.81 \pm 0.06 \mathrm{~b}$ & $1.01 \pm 0.08$ & $0.32 \pm 0.06 \mathrm{~b}$ & $0.79 \pm 0.03 \mathrm{a}$ & $0.37 \pm 0.01$ \\
\hline 40 I-Fe-Zn & $3.89 \pm 0.32$ & $49.88 \pm 4.21$ & $2.10 \pm 0.16$ & $1.08 \pm 0.11 \mathrm{a}$ & $1.29 \pm 0.14$ & $0.97 \pm 0.38 \mathrm{a}$ & $0.75 \pm 0.02 \mathrm{a}$ & $0.32 \pm 0.02$ \\
\hline$F$ & 1.94 & 2.50 & 3.22 & 6.23 & 0.83 & 3.29 & 5.81 & 2.43 \\
\hline LSD & ns & ns & ns & $0.21 * *$ & $\mathrm{~ns}$ & $0.60 *$ & $0.06^{* *}$ & ns \\
\hline
\end{tabular}

ns non-significant; $* P<0.05 ; * * P<0.01$

Levels of treatment had no statistically significant effect on the $\mathrm{Cu}, \mathrm{Mn}, \mathrm{Mo}, \mathrm{Cl}, \mathrm{Al}, \mathrm{Ni}, \mathrm{Co}$ and Ce concentrations of the plant and fruit (Table 5).

Table 5. Effect of combined iodine, iron and zinc treatment on plant and fruit $\mathrm{Cu}, \mathrm{Mn}, \mathrm{Mo}, \mathrm{Cl}, \mathrm{Al}, \mathrm{Ni}, \mathrm{Co}$ and $\mathrm{Ce}$ concentrations

\begin{tabular}{|c|c|c|c|c|c|c|c|}
\hline \multirow{2}{*}{ Treatments } & \multicolumn{7}{|c|}{ Plant $\left(\mathrm{g} \mathrm{kg}^{-1} \mathrm{DW}\right)$} \\
\hline & $\mathbf{C u}$ & Mn & Mo & Cl & $\mathrm{Ni}$ & Co & $\mathrm{Ce}$ \\
\hline Control & $7.08 \pm 0.69$ & $55.0 \pm 6.50$ & $1.43 \pm 0.09$ & $16.3 \pm 3.17$ & $3.48 \pm 0.77$ & $1.93 \pm 0.47$ & $14.55 \pm 1.27$ \\
\hline 10 I-Fe-Zn & $7.58 \pm 0.21$ & $58.1 \pm 6.15$ & $2.58 \pm 0.32$ & $17.4 \pm 0.60$ & $3.95 \pm 0.45$ & $1.93 \pm 0.40$ & $15.00 \pm 2.00$ \\
\hline 20 I-Fe-Zn & $6.73 \pm 0.98$ & $54.3 \pm 3.78$ & $2.25 \pm 0.66$ & $16.9 \pm 1.06$ & $3.75 \pm 0.47$ & $2.70 \pm 0.34$ & $14.57 \pm 1.57$ \\
\hline 40 I-Fe-Zn & $6.10 \pm 0.57$ & $51.5 \pm 1.94$ & $1.93 \pm 0.27$ & $16.7 \pm 0.65$ & $3.33 \pm 0.36$ & $2.35 \pm 0.79$ & $15.88 \pm 1.07$ \\
\hline$F$ & 0.85 & 0.30 & 1.55 & 0.08 & 0.27 & 0.50 & 0.17 \\
\hline \multirow[t]{2}{*}{ LSD } & ns & $\mathrm{ns}$ & ns & ns & ns & ns & ns \\
\hline & \multicolumn{7}{|c|}{ Fruit $\left(\mathrm{g} \mathrm{kg}^{-1} \mathrm{DW}\right)$} \\
\hline Control & $7.15 \pm 0.58$ & $11.20 \pm 0.35$ & $1.43 \pm 0.08$ & $4.16 \pm 0.25$ & $1.58 \pm 0.15$ & $0.73 \pm 0.06$ & $16.25 \pm 2.16$ \\
\hline 10 I-Fe-Zn & $7.80 \pm 0.65$ & $12.40 \pm 0.84$ & $1.75 \pm 0.10$ & $4.95 \pm 1.16$ & $2.50 \pm 0.35$ & $0.95 \pm 0.25$ & $14.57 \pm 1.92$ \\
\hline 20 I-Fe-Zn & $7.60 \pm 0.22$ & $14.15 \pm 1.54$ & $2.45 \pm 0.56$ & $4.28 \pm 0.41$ & $2.10 \pm 0.24$ & $0.88 \pm 0.28$ & $18.32 \pm 1.93$ \\
\hline 40 I-Fe-Zn & $9.10 \pm 0.88$ & $19.57 \pm 3.98$ & $1.68 \pm 0.37$ & $5.09 \pm 0.54$ & $3.65 \pm 1.48$ & $1.92 \pm 1.04$ & $16.40 \pm 1.51$ \\
\hline$F$ & 1.79 & 2.88 & 1.67 & 0.47 & 1.29 & 0.97 & 0.66 \\
\hline LSD & $\mathrm{ns}$ & $\mathrm{ns}$ & ns & ns & $\mathrm{ns}$ & ns & ns \\
\hline
\end{tabular}

ns, non-significant. 
Biofortification treatments at all levels had no significant effect on $\mathrm{Cr}, \mathrm{Ti}, \mathrm{Ga}, \mathrm{Rb}$ and $\mathrm{Ba}$ concentrations both plant and fruits out of the $\mathrm{Br}$ concentration of plant. Compared to the control, $\mathrm{Br}$ concentration in the plants and $\mathrm{Sr}$ concentration of fruits significantly increased; however, there were no effect on the other elements (Table 6).

Table 6. Effect of combined iodine, iron and zinc treatment on plant and fruit $\mathrm{Cr}, \mathrm{Ti}, \mathrm{Ga}, \mathrm{Br}, \mathrm{Rb}, \mathrm{Ba}$ and $\mathrm{Sr}$ concentrations

\begin{tabular}{|c|c|c|c|c|c|c|c|}
\hline \multirow{2}{*}{ Treatments } & \multicolumn{7}{|c|}{ Plant (mg kg-1 DW) } \\
\hline & $\mathrm{Cr}$ & $\mathbf{T i}$ & $\mathbf{G a}$ & $\mathbf{B r}$ & $\mathbf{R b}$ & $\mathbf{B a}$ & $\mathbf{S r}$ \\
\hline Control & $4.43 \pm 0.96$ & $49.95 \pm 6.58$ & $0.50 \pm 0.12$ & $20.68 \pm 3.29 \mathrm{~b}$ & $3.03 \pm 0.29$ & $50.28 \pm 5.51$ & $222 \pm 31.70$ \\
\hline 10 I-Fe-Zn & $5.63 \pm 1.50$ & $52.17 \pm 3.68$ & $0.48 \pm 0.12$ & $27.23 \pm 1.07 \mathrm{a}$ & $3.45 \pm 0.19$ & $51.65 \pm 2.36$ & $227 \pm 19.30$ \\
\hline $20^{1}$ I-Fe-Zn & $5.67 \pm 1.42$ & $59.55 \pm 6.77$ & $0.78 \pm 0.30$ & $28.80 \pm 0.74 \mathrm{a}$ & $3.35 \pm 0.16$ & $52.40 \pm 3.23$ & $244 \pm 7.92$ \\
\hline 40 I-Fe-Zn & $4.33 \pm 0.51$ & $67.05 \pm 6.48$ & $0.55 \pm 0.13$ & $28.72 \pm 1.82 \mathrm{a}$ & $2.93 \pm 0.17$ & $53.95 \pm 0.44$ & $260 \pm 9.83$ \\
\hline$F$ & 0.40 & 1.66 & 0.56 & 3.75 & 1.51 & 0.20 & 0.79 \\
\hline \multirow[t]{2}{*}{ LSD } & ns & ns & ns & $6.13 *$ & ns & ns & ns \\
\hline & \multicolumn{7}{|c|}{ Fruit (mg kg-1 DW) } \\
\hline Control & $2.53 \pm 0.09$ & $3.58 \pm 1.22$ & $0.30 \pm 0.07$ & $4.38 \pm 0.86$ & $4.38 \pm 0.34$ & $12.40 \pm 2.16$ & $5.53 \pm 0.90 \mathrm{~b}$ \\
\hline 10 I-Fe-Zn & $3.30 \pm 0.80$ & $3.35 \pm 1.04$ & $0.45 \pm 0.10$ & $4.45 \pm 0.16$ & $4.80 \pm 0.15$ & $6.63 \pm 0.43$ & $4.20 \pm 0.25 b$ \\
\hline 20 I-Fe-Zn & $2.75 \pm 0.10$ & $1.73 \pm 0.13$ & $0.23 \pm 0.03$ & $5.30 \pm 0.72$ & $4.85 \pm 0.23$ & $9.35 \pm 1.90$ & $5.15 \pm 0.48 \mathrm{~b}$ \\
\hline 40 I-Fe-Zn & $3.20 \pm 0.27$ & $1.87 \pm 0.09$ & $0.38 \pm 0.11$ & $6.30 \pm 0.62$ & $5.93 \pm 0.58$ & $11.10 \pm 2.94$ & $7.70 \pm 0.84 \mathrm{a}$ \\
\hline$F$ & 0.74 & 1.44 & 1.30 & 1.94 & 3.29 & 1.45 & $4.81 *$ \\
\hline LSD & $\mathrm{ns}$ & $\mathrm{ns}$ & $\mathrm{ns}$ & ns & ns & ns & 2.08 \\
\hline
\end{tabular}

ns non-significant; $* P<0.05$

Levels of combined I-Fe-Zn treatments had no statistically significant effects on the concentrations of Sn, Cs, Ge, Sb, Ta, Te and Hf both plant and fruits (Table 7).

Table 7. Effect of combined iodine, iron and zinc treatment on plant and fruit $\mathrm{Sn}, \mathrm{Cs}, \mathrm{Ge}, \mathrm{Sb}$, Ta, Te and Hf concentrations

\begin{tabular}{|c|c|c|c|c|c|c|c|}
\hline \multirow{2}{*}{ Treatments } & \multicolumn{7}{|c|}{ Plant (mg kg ${ }^{-1}$ DW) } \\
\hline & Sn & Cs & $\mathbf{G e}$ & $\mathrm{Sb}$ & Ta & Te & Hf \\
\hline Control & $0.95 \pm 0.16$ & $5.70 \pm 0.82$ & $0.23 \pm 0.03$ & $0.88 \pm 0.03$ & $1.20 \pm 0.21$ & $1.08 \pm 0.16$ & $1.35 \pm 0.16$ \\
\hline $10 \mathrm{I}-\mathrm{Fe}-\mathrm{Zn}$ & $0.85 \pm 0.03$ & $5.63 \pm 1.26$ & $0.20 \pm 0.01$ & $0.95 \pm 0.03$ & $1.45 \pm 0.06$ & $1.48 \pm 0.11$ & $1.40 \pm 0.39$ \\
\hline $20 \mathrm{I}-\mathrm{Fe}-\mathrm{Zn}$ & $0.90 \pm 0.00$ & $4.23 \pm 0.31$ & $0.20 \pm 0.01$ & $0.95 \pm 0.12$ & $1.05 \pm 0.25$ & $1.40 \pm 0.04$ & $1.58 \pm 0.19$ \\
\hline $40 \mathrm{I}-\mathrm{Fe}-\mathrm{Zn}$ & $0.95 \pm 0.03$ & $4.23 \pm 0.06$ & $0.20 \pm 0.01$ & $0.95 \pm 0.09$ & $1.35 \pm 0.27$ & $1.53 \pm 0.33$ & $1.33 \pm 0.18$ \\
\hline$F$ & 0.35 & 1.17 & 1.00 & 0.24 & 0.65 & 1.10 & 0.21 \\
\hline \multirow[t]{2}{*}{ LSD } & n.s & n.s & n.s & n.s & n.s & n.s & n.s \\
\hline & \multicolumn{7}{|c|}{ Fruit (mg kg ${ }^{-1}$ DW) } \\
\hline Control & $1.05 \pm 0.32$ & $5.53 \pm 0.83$ & $0.15 \pm 0.03$ & $0.85 \pm 0.03$ & $1.15 \pm 0.03$ & $1.53 \pm 0.26$ & $1.00 \pm 0.11$ \\
\hline $10 \mathrm{I}-\mathrm{Fe}-\mathrm{Zn}$ & $0.93 \pm 0.13$ & $4.15 \pm 0.03$ & $0.40 \pm 0.20$ & $0.88 \pm 0.03$ & $1.20 \pm 0.04$ & $1.23 \pm 0.19$ & $1.63 \pm 0.23$ \\
\hline $20 \mathrm{I}-\mathrm{Fe}-\mathrm{Zn}$ & $0.83 \pm 0.03$ & $5.95 \pm 1.18$ & $0.15 \pm 0.03$ & $0.85 \pm 0.03$ & $1.05 \pm 0.16$ & $1.28 \pm 0.03$ & $1.10 \pm 0.15$ \\
\hline $40 \mathrm{I}-\mathrm{Fe}-\mathrm{Zn}$ & $0.85 \pm 0.05$ & $4.20 \pm 0.01$ & $0.23 \pm 0.03$ & $0.90 \pm 0.06$ & $2.78 \pm 1.85$ & $1.25 \pm 0.03$ & $3.72 \pm 2.33$ \\
\hline$F$ & 0.34 & 1.64 & 1.32 & 0.41 & 0.78 & 0.74 & 1.17 \\
\hline LSD & ns & ns & $\mathrm{ns}$ & $\mathrm{ns}$ & $\mathrm{ns}$ & $\mathrm{ns}$ & $\mathrm{ns}$ \\
\hline
\end{tabular}

ns, non-significant

\section{CONCLUSION}

Especially in developing countries, people needs daily intake such as Fe, $\mathrm{Zn}$ and I which essential for people. This study is the first proof to determine the effect of combined I-Fe- $\mathrm{Zn}$ treatments on concentrations of $\mathrm{I}, \mathrm{Fe}$ and $\mathrm{Zn}$ with yield and it shows that biofortification was an important way to eliminate of these three elements deficiency in plants.

\section{REFERENCES}

Anonymous, 2009. World Health Organization of the United Nations. 2009. Global Health Risks: Mortality and Burden of Disease Attributable to Selected Major Risks. WHO, Geneva (Date of access: 15.10.2019).

Anonymous, 2017. Dietary Reference Values for Nutrients Summary Report, European Food Safety Authority (EFSA), December 2017 (Date of access: 15.10.2019).

Anonymus, 2019. National Institutes of Health: Iron Dietary Supplement Fact Sheet. 2016 (Date of access: 20.11.2019).

Blasco B, Rios JJ, Cervilla LM, Sanchez-Rodrigez E, Ruiz JM, Romero 1, 2008. Iodine Biofortification and

Antioxidant Capacity of Lettuce: Potential Benefits for Cultivation and Human Health. Annals of Applied Biology, 152: 289-299. 
Bouis HE, Hotz C, McClafferty B, Meenakshi, JV, Pfeiffer WH, 2011. Biofortification: A New Tool to Reduce Micronutrient Malnutrition. Food and Nutrition Bulletin, 32: 31-40.

Cakmak I, 2008. Enrichment of Cereal Grains With Zinc: Agronomic or Genetic Biofortification?. Plant and Soil, 302: 1-17.

Cakmak I, Pfeiffer WH, McClafferty B, 2010. Biofortification of Durum Wheat with Zinc and Iron. Cereal Chemistry, 87: 10-17.

Cakmak I, Kutman UB, 2018. Agronomic Biofortification of Cereals with Zinc: A Review. Europen Journal of Soil Science, 69: 172-180.

Clemens S, 2014. Zn and Fe Biofortification: The Right Chemical Environment for Human Bioavailability. Plant Science, 225: 52-57.

Dai JL, Zhu YG, Huang YZ, Zhang M, Song J, 2006. Availability of Iodide and Iodate to Spinach (Spinacia oleracea L.) in Relationto Total Iodine in Soil Solution. Plant and Soil, 289: 301-308.

Diaz-Gomez J, Twyman RM, Zhu C, Farre G, Serrano J, Portero-Otin M, Munoz P, Sandmann G, Capell T, Christou P, 2017. Biofortification of Crops with Nutrients: Factors Affecting Utilization and Storage. Current Opinion in Biotechnology, 44: 115-123.

Dimkpa CO, Bindraban PS, 2016. Fortification of Micronutrients for Efficient Agronomic Production: A Review, Agronomy for Sustainable Development, 36: 7-27.

FAO, 2019. http://www.fao.org/faostat/en/\#data/QC. (Date of access: 12.01.2020)

Garcia-Alonso M, Pascual-Teresa S, Santos-Buelga C, Rivas-Gonzalo JC, 2004. Evaluations of the Antioxidant Properties of Fruit, Food Chemistry, 84: 13-18.

Gillooly M, Bothwell TH, Torrance JD, MacPhail AP, Derman DP, Bezwoda WR, Mills W, Charlton RW, 1983. The Effects of Organic Acids, Phytates and Polyphenols on the Absorption of Iron from Vegetables. British Journal of Nutrition, 49: 331-342.

Gioia DF, Petropoulos SA, Ozores-Hampton M, Morgan K, Rosskopf EN, 2019. Zinc and iron agronomic biofortification of Brassicaceae microgreens, Agronomy, 9: 1-20.

Giordano M, El-Nakhel C, Pannico A, Kyriacou MC, Stazi ST, Pascale S, Rouphael Y, 2019. Iron Biofortification of Red and Green Pigmented Lettuce in Closed Soilless Cultivation Impacts Crop Performance and Modulates Mineral and Bioactive Composition. Agronomy Journal, 290: 1-21.

Gonzali S, Kiferli C, Perata P, 2017. Iodine Biofortification of Crops: Agronomic Biofortification, Metabolic Engineering and Iodine Bioavailability. Current Opinion Biotechnology, 44: 16-26.

Grillet L, Mari S, Schmidt W, 2014. Iron in Seeds Loading Pathways and Subcellular Localization, Frontiers in Plant Science, 4: 1-8.

Guo JX, Feng XM, Hu XY, Tian GL, Ling N, Wang JH, Shen QR, Guo SW, 2016. Effects of Soil Zinc Availability, Nitrogen Fertilizer Rate and Zinc Fertilizer Application Method on Zinc Biofortification of Rice. Journal of Agricultural Science, 154: 584-597.

Gunes A, Inal A, Pilbeam DJ, Kadioglu YK, 2009. Determination of Mineral Element Concentrations in Wheat, Sunflower, Chickpea and Lentil Cultivars in Response to Phosporus Fertilization by Polarized Energy Disperse X-ray flurescence. X-ray Spectrometry, 38: 451-462.

Hetzel B, 1989. The Story of Iodine Deficiency. Delhi: Oxford University Press.

Hetzel B, Pandav C, 1994. S.O.S. for a Billion. The Conquest of Iodine Deficiency Disorders. Delhi: Oxford University Press.

Hong C, Weng H, Qin Y, Yan A, Xie L, 2008. Transfer of Iodine from Soil to Vegetables by Applying Exogenous Iodine. Agronomy for Sustainable Development, 28: 575-583.

Humphrey OS, Young SD, Bailey EH, Crout NMJ, Ander EL, Hamilton EM, Watts MJ. 2019. Iodine Uptake, Storage and Translocation Mechanisms in Spinach (Spinacia oleracea L.). Environmental Geochemistry and Health, 41: 1-12.

Incrocci L, Carmassi G, Maggini R, Poli C, Saidov D, Tamburini C, Kiferli C, Perata P, Pardossi A. 2019. Iodine Accumulation and Tolerance in Sweet Basil (Ocimum basilicum L.) with Green or Purple Leaves Grown in Floating System Technique. Frontier in Plant Science, 10: 1-15. 
Islam MZ, Mele MA, Baek JP, Kang H. 2018. Iron, Iodine and Selenium Effects on Quality, Shelf Life and Microbial Activity of Cherry Tomatoes. Notulae Botanicae Horti Agrobobotanica Cluj-Napoca, 46: 388392.

Kiferli C, Gonzali S, Holwerda HT, Ibaceta RR, Perata P, 2013. Tomato fruits: A Good Target for Iodine Biofortification. Frontier in Plant Science, 4: 1-10.

Krzepilko A, Zych-Wezyk I, Molas A, 2015. Alternative Ways of Enriching the Human Diet with Iodine. Journal Pre-Clinical and Clinical Research, 9: 167-171.

Krzepilko A, Zych-Wezyk I, Swiecilo A, Molas, Skwarylo-Bednarz B, 2016. Effect of Iodine Biofortification of Lettuce Seedlİngs on Their Mineral Composition and Biological Quality. Journal of Elementology, 21: 1071-1080.

Kumar S, Palve A, Joshi C, Srivastava RK, Rukhsar, 2019. Crop biofortification for Iron (Fe), Zinc (Zn) and Vitamin a with Transgenic Aapproaches. Heliyon, 5: 1-6.

La Frano MR, De Moura FF, Boy E, Lönnerdal B, Burri BJ, 2014. Bioavailability of Iron, Zinc, and Provitamin A Carotenoids in Biofortified Staple Crops. Nutrition Reviews, 72: 289-307.

Landini M, Gonzali S, Perat P, 2011. Iodine Biofortification in Tomato. Journal of Plant Nutrition and Soil Science, 174: 480-486.

Li R, Liu HP, Hong CL, Dai ZX, Liu JW, Zhou J, Hua CQ, Weng HX, 2017a. Iodide and Iodate Effects on the Growth and Fruit Quality of Strawberry. Journal of Plant Nutrition and Soil Science, 97: 230-235.

Li R, Li WD, Liu HP, Hong CL, Song MY, Dai ZX, Liu JW, Zhou J, Weng HX, 2017b. Enhanching Iodine Content and Fruit Guality of Pepper (Capsicum annuum L.) through Biofortification. Scientia Horticulturae, 214: 165-173.

Lin NF, Tang J, Bian JM, 2004. Geochemical Environment and Health Problems in China. Environmental Geochemistry and Heath, 26: 81-88.

Lyons G, 2018. Biofortification of Cereals with Foliar Selenium and Iodine Could Reduce Hypothyroidism. Food and Nutrition Bulletin, 9: 730-738.

Majumber S, Datta K, Datta K, 2019. Rice Biofortification: High Iron, Zinc, and Vitamin-A to Fight against 'Hidden Hunger'. Agronomy, 803: 1-22.

Maqbool MA, Beshir A, 2018. Zinc Biofortification of Maize (Zea mays L.): Status and Challenges. Plant Breeding, 138: 1-28.

Page AL, 1982. Methods of Soil Analysis. Part 2, Chemical and Microbiological properties, 2nd edn. American Society of Agronomy Inc. Soil Science Society of America Inc. Madison, WI.

Patel P, Trivedi G, Saraf M, 2018. Iron Biofortification in Mungbean Using Siderophore Producing Plant Growth Promoting Bacteria. Environmental Sustainability, 1: 357-365.

Prasad R, Shivay YS, Kumar D, 2014. Agronomic Biofortification of Cereal with Iron and Zinc. Advenced in Agronomy, 125: 55-91.

Przybysz A, Wrochna M, Malecka-Przybysz M, Gawronska H, 2016. Vegetable Sprouts Enriched with Iron: Effects on Yield, ROS Generation and Antioxidative System. Scientia Horticulturae, 203: 110-117.

Salgueiro MJ, Zubillaga M, Lysionek A, Cremaschi G, Goldman CG, Caro R, De Paoli T, Hager A, Weill R, Boccio J, 2000. Zinc Status and Immune System Relationship: A Review. Biological Trace Element Research, 76:193-205.

Sazawal S, Dhingra, Dhingra P, Dutta A, Deb S, Kumar J, Devi P, Prakash A, 2018. Efficacy of High Zinc Biofortified Wheat in Improvement of Micronutrient Status, and Prevention of Morbidity among Preschool Children and Women - a Double Masked, Randomized, Controlled Trial. Nutritional Journal, 17: 1-10.

Shahzad Z, Rouached H, Rakka A, 2014. Combating Mineral Malnutrition through Iron and Zinc Biofortification of Cereals. Comprehensive Reviews in Food Science and Food Safety, 13. 329-346.

Siegenberg D, Baynes RD, Bothwell TH, Macfarlane BJ, Lamparelli RD, Car NG, MacPhail P, Schmidt U, Tal A, Mayet F, 1991. Ascorbic Acid Prevents the Dose-Dependent Inhibitory Effects of Polyphenols and Phytates on Nonheme-Iron Absorption. The American Journal of Clinical Nutrition, 53: 537-541. 
Smolen S, Sady W, 2011. Influence of Soil Application of Iodine and Sucrose on Mineral Composition of Spinach Plants. Acta Scientiarum Polonorum Hortorum Cultus, 10: 3-13.

Smolen S, Sady W, 2012. Influence of Iodine Form and Application Method on the Effectiveness of Iodine Biofortification, Nitrogen Metabolism as well as the Content of Mineral Nutrients and Heavy Metals in Spinach Plants (Spinacia oleracea L.). Scientia Horticulturae, 143: 176-183.

Sperotto RA, Ricachenevsky FK, Waldow VA, 2012. Iron Biofortification in Rice: It's a Long Way to the Top. Plant Science, 190: 24-39.

Stein AJ, 2010. Global Impact of Human Mineral Malnutrition. Plant and Soil, 335: 133-154.

Voogt W, Holwerda, HT, Khodabaks R, 2010. Biofortification of Lettuce (Lactuca sativa L.) with Iodine: The Effect of Iodine Form and Concentration in the Nutrient Solution on Growth, Development and Iodine Uptake of Lettuce Grown in Water Culture. Journal of the Science of Food and Agricultare, 90: 906-913.

Welch RM, Graham RD, Cakmak I, 2013. Linking Agricultural Production Practices to Improving Human Nutrition and Health. Expert Paper Written for ICN2 Second International Conference on Nutrition Preparatory Technical Meeting, November 13-15, 2013, Rome, Italy.

Weng HX, Weng JK, Yong WB, Sun XW, Zhong H, 2003. Capacity and Degree of Iodine Absorbed and Enriched by Vegetable from Soil. International Journal of Environ Scienceand Technology, 15: 107-111.

Weng HX, Yan AL, Hong CL, Xie LL, Qin YC, Cheng CQ, 2008. Uptake of Different Species of Iodine by Water Spinach and its Effect to Growth. Biological Trace Element Research, 124: 184-194.

Weng HX, Hong CL, Xia TH, Bao LT, Liu HP, DeWang L, 2013. Iodine Biofortification of Vegetable Plants-An Innovative Method for Iodine Supplementation. Chinese Science Bulletin, 58: 2066-2072.

White PJ, Broadley MR, 2009. Biofortification of Crops with Seven Mineral Elements Often Lacking in Human Diets Iron, Zinc, Copper, Calcium, Magnesium, Selenium and Iodine. New Phytologist, 182: 49-84.

White PJ, Broadley MR, 2011. Physiological Limits to Zinc Biofortification of Edible Crops. Frontiers in Plant Science, 2: 1-11.

Woch E, Hawrylak-Nowak B, 2019. Selected Antioxidant Properties of Alfalfa, Radish, and White Mustard Sprouts Biofortified with Selenium. Acta Agrobotonica, 72: 1-11.

Zaman, Q, AslamZ, Yaseen M, Ihsan MZ, Khaliq A, Fahad S, Bashir S, Ramzani PMA, Naeem M, 2018. Zinc Biofofortification in Rice. Levearing Agriculture to Moderate Hidden Hunger in Developing Countries. Archives of Agronomy and Soil Science, 64: 147-161.

Zhu YG, Huang YZ, Hu Y, Liu YX, 2003. Iodine Uptake by Spinach (Spinacia oleracea L.) Plants Grown in Solution Culture: Effects of Iodine Species and Solution Concentrations. Environment International, 29: 33-37.

Zou C, Du Y, Rashid A, Ram H, Savasli E, Pieterse PJ, Ortiz-Monasterio I, Yazici A, Kaur C, Mahmood K, Singh S, Le Roux, MR, Kuang W, Onder O, Kalayci M, Cakmak I, 2019. Simultaneous Biofortification of Wheat with Zinc, Iodine, Selenium, and Iron through Foliar Treatment of a Micronutrient Cocktail in Six Countries. Journal of Agricultural and Food Chemistry, 67: 8096-8106. 